\title{
'I dare': experiences of young adults at risk participating in a one-year inclusive-theatre project in Norway
}

\author{
Ellen Andvig* \\ Faculty of Health and Social Sciences \\ University College of Southeast Norway \\ Email: ellen.andvig@usn.no \\ *corresponding author \\ Jan Kåre Hummelvoll \\ Faculty of Health and Social Sciences \\ University College of Southeast Norway \\ Email: jankhum@online.no
}

\begin{abstract}
Introduction: In Norway one of three young people drop out of high school. For young people to be on the outside of education or work may develop feelings of isolation and lack of control, resulting in alienation from both authority and community that may further marginalize them. Some develop mental-health problems.

Aim: The aim of this study was to describe and interpret the experiences of young persons neither in school nor working who participated in a one-year inclusive-theatre project. The research questions were as follows: How do the participants describe their experiences with inclusive theatre related to selfimage? How does participating in inclusive theatre affect their social belonging and participation?

Method: Three multi-stage focus-group interviews with participants were carried out. The data material was analysed with thematic content analysis.

Findings: The main theme was 'a changed self-image' and four sub-themes emerged: 'increased self-confidence', 'increased ability to cope', 'responsibility', and 'connectedness to others and society'.

Conclusion: Through increased self-esteem, the participants explored opportunities to form their own development and to find a way to pursue their goals as part of society. They dared to meet the challenges which had provided them with good experiences and a more meaningful life. They went through a social process of empowerment where there was the recognition, promotion, and strengthening of their ability to satisfy their own needs, involving a mobilization of the necessary resources in order to feel in control of their own lives. They began to believe in a future with education, work, and friends.
\end{abstract}


Keywords: empowerment, inclusive theatre, mental-health problems, school dropout, social belonging, social participation, young adults at risk

\section{Introduction}

There is a rising demand for education in society today. A college education is important for young people who want access to good jobs (Settersten \& Ray, 2010). However, in the Norwegian context, a completed upper high school with a two years' apprenticeship in one of the many recognized trades, which results in a trade certificate, can also give access to a high number of good jobs. A lack of education may contribute to adverse life-course consequences, for instance, poor health and demands on social-welfare entitlements (Costello et al., 2005; Patel et al., 2007). For young people, not attending school or working may develop feelings of isolation and a lack of control, resulting in alienation from authority and community, which may further marginalize them (Thompson et al., 2013). The rates of high-school dropouts is a national problem in countries all over the world and has an impact on both the individual and the society (Lee et al., 2009). The termination of high school before completion is a result of many different factors on different levels - individual, institutional, social, and so on. As Rumberger and Lim (2009, p. 2) state, 'It is virtually impossible to demonstrate a causal connection between any single factor and the decision to quit school'.

In Norway one of three drop out of school or do not complete high school within five years (NOVA, 2014). A Norwegian study (Ramsdal et al., 2013) reported that several young people who had dropped out of school had experiences of abandonment, academic demotivation, social marginalization and exclusion, and being lonely. Some of them struggled with mental-health problems and substance abuse (Langeland et al., 2014). They are often called 'youth at risk', defined as those experiencing complex difficulties and problems, necessitating services from at least two public agencies (NOU, 2009, No. 22). Young people, on the other hand, draw a picture of risk that involves themselves. They are concerned with loneliness, being overseen or being insignificant to anyone (Follesø, 2011).

The Norwegian white paper on public health, 'Coping and possibilities' (The Norwegian Ministry of Health and Care Services, 2014-2015), underscores the importance of a national commitment to help more young people to complete high school. The focus on mental health in schools is to be further developed and to be given a stronger grounding in school. According to this white paper, there is a need for more knowledge and examples of good practices of how to work with the mental-health issues of children and adolescents in school. A Nordic report (Hyggen, 2015) on young people neither attending school nor working pointed to the importance of securing the implementation of their education and inclusion in the labour market. The report underlines the importance of acknowledging alternative routes to the labour market and allowing for more time to find their own way to acquire the skills they need. Various 'Green Care' enterprises have, for example, been shown to have a beneficial effect on youth in vulnerable situations where there is a risk of social exclusion (Granerud \& Eriksson, 2014; Steigen, Kogstad \& Hummelvoll, 2016). These enterprises represent alternative arenas in which people can work with animals, agriculture, and other nature-related tasks (Kogstad, Agdal \& 
Hopfenbeck, 2015). An alternative approach to inclusion of young people at risk is the model called Individual Placement and Support. This model aims to help persons with mental-health problems to find and stay employed in ordinary jobs (Drake \& Becker, 2006). The method has been tried out on young people with mental-health problems and it has achieved good results (Bond et al., 2012; Ellison et al., 2014).

A report from the Nordic Council of Ministers (Halvorsen et al., 2012) has found that there are many projects and development works with good methods and results that are getting young people back to school and to work. However, few projects have been evaluated. Therefore, the report recommends that more systematic knowledge concerning these development works is needed. The present article is one response to this request.

The aim of this study has been to describe and interpret the experiences of young persons who are neither in school nor at work who have participated in inclusive theatre. The research questions were as follows:

How do young people describe experiences with inclusive theatre related to self-image?

How does participating in inclusive theatre affect young people's experience of social belonging and participation?

\section{Inclusive theatre}

Inclusive theatre aims at stimulating emancipation and social participation (Gürgens, 2004; Gjærum \& Rasmussen, 2010; Gjærum et al., 2010). It was originally designed as a theatrical activity for disabled people. The goal was to include disabled and well-functioning individuals in the same theatre. This was later expanded to include other often-marginalized groups who had few opportunities to participate in theatrical activities (Gürgens, 2004). The purpose of inclusive theatre is both to provide social inclusion and to serve as a framework for the development of social skills and self-confidence. Inclusive theatre also seeks to be a space for the greater visibility of marginalized groups, and giving them an opportunity to make their voices heard in the public arena (Gürgens, 2004; Wooster, 2009). In this way it can function as an empowering arena where the actors are liberated from their roles as marginalized persons (Gjærum \& Rasmussen, 2010).

Inclusive theatre seems to have much in common with community-based theatre. Wooster (2009) uses the concept 'inclusive community theatre'. Faigin and Stein (2010) describe community-based theatre as a form of inclusive, socio-political theatre that takes a critical position toward social issues, aims to raise awareness, and works to resolve social frustrations and conflict. This form of theatre has a perspective of community-citizen empowerment and social justice (Faigin \& Stein, 2010).

\section{Theatre and creative arts in work with young people}

The use of theatre and performing arts programmes for the sake of the emancipation of different oppressed groups has been utilized among migrant communities (Hawkins \& Georgokopolus, 2010), asylum seekers (Horghagen \& Josephsson, 2010), and young people exposed to or perpetrating bullying (Bhukhanwala, 2014). It has also been implemented in high schools to stimulate emotional development (Larson \& Brown, 2007) and flourishing (Kane, 2013)

NJSR - Nordic Journal of Social Research 
and to develop empowerment and social change for incarcerated and young people at risk (Mohler, 2012).

Anticipated effects reported by Mohler (2012) are that participating in ensemble theatre and performing arts had the potential to empower youth by increasing their sense of agency and creative autonomy. A literature review by Daykin et al. (2008) has reported some evidence of positive outcomes following performing-arts interventions for young people. The review provided insight into some of the impact and processual issues associated with the arts for health initiatives. The strongest evidence was connected to the impact of drama on peer interaction and social skills, where they found the largest number of studies.

A literature review by Bungay and Vella-Burrows (2013) has found that a number of the studies reported on projects which were introduced with the purpose of helping to build communities and to increase social engagement. Creative activities have also been used to promote behavioural change and healthy lifestyles. By participating in such programmes children and young people were less likely to abuse substances, exhibited improved behaviour, and developed a range of interpersonal skills. The most commonly reported outcome in all the studies reviewed was that of increased confidence. Increased self-esteem, sense of achievement, empowerment, social skills, and positive behavioural changes were also consistently reported outcomes in the review.

\section{Theoretical inspirations: pedagogy and theatre of the oppressed}

Paulo Freire's (1970) views on democratic education were to help people fight back as a group and to participate in the process of counteracting selfoppression. Freire's 'pedagogy of the oppressed' has been an important basis for the empowerment ideology. According to this ideology a central goal is that disempowered groups break out of their suppressed situation and through consciousness-raising are able to fight difficult situations and to become equal, competent citizens in society (Askheim, 2003). WHO (1998) understands empowerment as a practice in which people achieve greater control over their own decisions and practices affecting their health. Today the concept of empowerment is widely used with a breadth of definitions. It mainly focuses on the individual level and is therefore often criticized for not taking social factors, such as social determinants of people's health, into consideration (Askheim, 2003; Woodall et al., 2012). Individual empowerment does not contribute to full empowerment in the sense of transforming the relations of power. Wodall et al. (2012) claim that empowerment in a way has lost its links with its original roots concerning social justice and wider power structures through social and structural change.

Inspired by Freire, Augusto Boal developed Theatre of the Oppressed to offer a theatrical space for people to come together to rehearse for reality, to engage in a critical dialogue, and to build a more humane environment (Boal, 2003; 2006). Boal is concerned with all sorts of oppression, socially, locally, and individually. His basic message is that participants can use the experience of theatre work to take the leading role in their own lives (Boal, 1995). It is important to use theatre to encourage empowerment, power, and determination of individuals, groups, and in society as a whole (Boal, 1995; 2006). Boal argues that the arts have the capacity to allow people to observe themselves in action, to imagine themselves as actors and agents of change. Theatre of the Oppressed is both a theoretical framework and a practice. Two core elements are praxis and the need for dialogue. Praxis has to do with the simultaneous 
action and reflection necessary to transform the world. This makes it possible for persons to analyse what they do as they do it. Boal claims that the theatre in its deepest sense is about our capacity to observe ourselves in action (Boal 1998 , p. 7). By developing our consciousness, we will be more human. Boal is also occupied with the importance of dialogue to establish mutual learning, by involving performers and audience in the performance, communicating together.

\section{The project 'I dare': an example of inclusive theatre}

Thirteen young people participated in this project: six men and seven women. The participants were called 'actors' (a term used hereafter). Theoretically and practically the project was inspired by the work of Augusto Boal and Pablo Freire. It had a dialogical nature and aimed to stimulate the empowerment and emancipation of the actors. The project also aimed to improve concentration, to stimulate creativity, and to develop collaboration and trust in others. Additional purposes were to practise being social and to experience a sense of belonging as an individual and as a group in society. The more long-term aim was to motivate the participants to attend school and to find employment. The project was financed by NAV - the Norwegian Labour and Welfare Service - through the programme FARVE (Development funds, work, and welfare).

The project 'I dare' was planned to last for a school year and took place in 20082009. The project leader, a drama teacher, and other professional artists worked with the actors. The topics they taught were choral singing, photography, theatre, awareness training, drama, improvisation, writing practice, music, and film. The topics also included learning of practical skills such as bicycle maintenance, cooking, and management of personal finances. The actors and staff participated in several cultural activities during evenings and weekends. The last half year, the programme focused more intensively on the upcoming theatrical performance.

During the project, actors and staff organized a variety of events and exhibitions with an audience present: a concert in the local cathedral, a photographic exhibition, teaching theatrical games for students at the university college, arranging a demonstration against the use of fur by Boal's method of 'Invisible Theatre'. They produced music videos and a documentary about the events in the project.

The project leader closely supervised the actors. They developed their own individual plan and set personal goals for the project participation. The project leader was available and encouraged the actors to take hold of their own personal and social problems.

Most of the elements of the creative activities the actors had worked on throughout the year were used in the performance, entitled Hanging from a thin line. The actors were involved in all aspects of script writing, production, and performing. The roles were tailored to each actor. The performance was about the myths and prejudices against young people with mental-health problems who had fallen out of society's established norms and how they could empower themselves by combating their barriers. 


\section{Methodology}

\section{Participants}

All 13 actors agreed to participate in the study (aged $18-23$ years, except for one at 27). When beginning in the project they had problems with loneliness, anxiety, and isolation, and they experienced little hope and meaning in life. They felt socially excluded, and some had problems with substance abuse. Many struggled with mental-health problems and a lack of education, work experiences, and networks. Several had problems with concentration and restlessness. Only a few had finished high school. Twelve of the actors completed the project. One actor quit in the final phase owing to experiencing too much pressure because of the high demands for participation.

\section{Multi-stage focus-group interviews}

The multi-stage focus group is characterized by the same group exploring a focused problem, theme or phenomenon in depth through several meetings. Through these dialogues, there are possibilities to 'elevate' the participants' experiences to a higher level of abstraction. Thus, the potential utility value of the knowledge exceeds the concrete situation in which it is created (Hummelvoll, 2008). Three multistage focus-group interviews with the actors were carried out. The meetings took place in the project's localities. There were 11 participants who met in the first and second focus groups, and 12 in the third. Two researchers were present: the first author led the interviews, and another health-professional researcher served as secretary and was responsible for observing the group process and making a summary at the end of each meeting. The summary aimed to investigate whether the views that emerged were properly understood. This often led to more nuanced views and clarifications.

Each focus-group interview lasted 90 minutes. The main focus was on the actors' subjective experiences of participating in the project. Before the second and the third interview, the actors received preliminary analyses.

\section{Data analysis}

The focus-group interviews were recorded and transcribed verbatim. The researchers then used qualitative content analysis to analyse the data (Graneheim \& Lundman, 2004), which they conducted in a stepwise manner. The transcribed text from the first focus group was condensed and an initial analysis was performed before the second and the third meeting. The second interview focused on topics initiated in the first interview. Finally, the researchers summarized the main theme and categories, sub-categories, and codes generated in the analysis based on data from all three focus groups (see Table 1). The researchers also identified codes and analytical traces. Statements from the interviews were systematized by collecting statements that fitted together under the different codes. The researchers identified and named the categories and sub-categories, and then validated the categories towards the transcribed interview and used examples of statements to validate the categories. Coherent perceptions, as well as majority and minority perceptions and opinions, were illuminated through abstractions and specific illustrations in relation to the content of the themes (Hummelvoll, 2008). The researchers then presented a draft of the analysis to two of the actors and discussed and revised it on the basis of their views. 


\section{Ethical considerations}

Ethical guidelines in line with the Declaration of Helsinki (World Medical Association, 2008) were followed in relation to confidentiality and anonymity. The researchers were particularly attentive to the ethical principles of informed consent, the right to privacy, respect for personal integrity, non-maleficence, and beneficence. They also received written informed consent from all participants. The right to withdraw without consequences for participation in the theatre project was emphasized. The researchers reported the study to the Data Protection Official for Research (NSD) and to The Regional Committee for Medical and Health Research. The latter found, however, that the project had no obligation to report the project.

\section{Methodological discussion}

The study of this project took place in 2008-2009. This may seem a long time ago, but the findings are just as relevant today as in 2009, because the dropout rate has been relatively stable $(30 \%)$ for the last twenty years in Norway (Statistics Norway, 2013).

Giving the actors a preliminary analysis between the focus-group meetings gave them the possibility to be involved in the analysis and to continue the reflections in the next meeting. This stimulated further dialogue and raised issues that could be further nuanced and deepened (Andvig, 2014).

An adjacent bias of multistage focus-group interviews is a pressure towards consensus, which means that the group expresses common understandings and attitudes when in fact divergent opinions exist. Whether this bias is prominent or not can be assessed by considering to what extent statements and attitudes are countered or experiences are met with nuances and counterexperiences.

The use of group interaction as data might allow exploration of insights that would otherwise remain hidden. A drawback might be that there were many participants in the focus groups, which could make the members of the group passive. Active participation, openness and trust characterized the group process, however. Disagreements were expressed and experiences were contradicted by opposite experiences (cf. Hummelvoll \& Severinsson, 2005).

\section{Findings}

The main theme is 'a changed self-image'. The sub-themes are 'increased selfconfidence', 'increased coping ability', 'responsibility', and 'connectedness to others and society'. 
Table 1 Overview of the findings, with main theme, themes content and examples of quotations

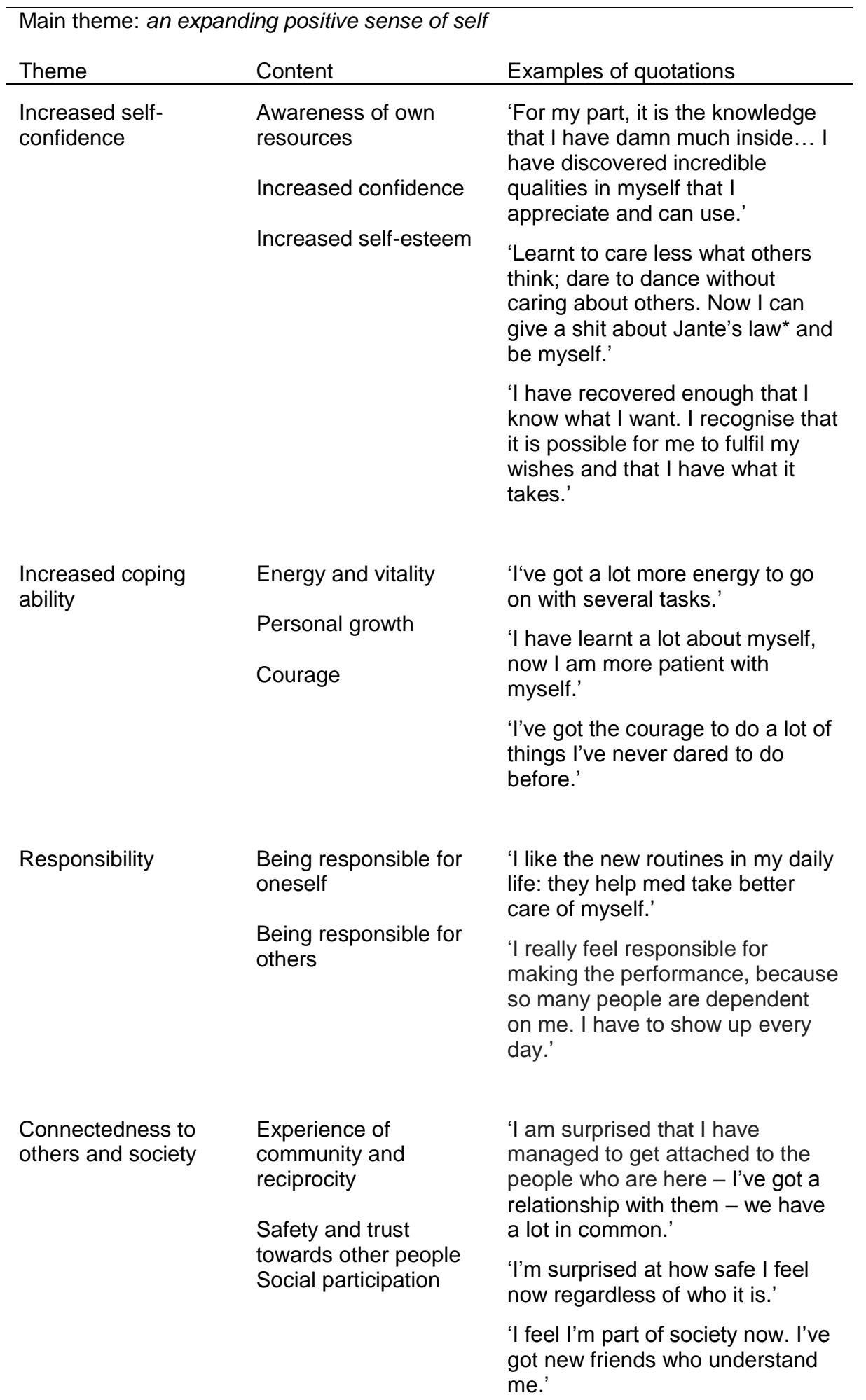

\footnotetext{
* 'Jante's law' is a Scandinavian term used to describe a prevalent culture that discourages
} individual success or expression. 


\section{Increased self-confidence}

The theme of 'increased self-confidence' consists of the sub-themes 'awareness of one's own resources', 'increased confidence' and 'increased selfesteem'. Regarding 'awareness of one's own resources', the actors learned that they had far more resources than they had imagined when they joined the project. They gradually experienced being capable persons. As one actor said, 'I have learnt that I have held back much inside. I have discovered an incredible number of aspects of myself that I now can appreciate and use'.

The actors experienced that the professionals believed in them and had confidence in them. These experiences confirmed that they had the resources to cope with the challenges they faced during the project. This affected their faith in themselves. One of the young women told about a powerful anxiety attack during an exercise on stage where she ran away and wanted to give up. When she came back the leader simply asked if she was ready for a new scene. Then she went up on stage and continued. She appreciated that her anxiety attack was seen as a natural reaction, and learning that it was harmless. She claimed this experience gave her increased self-confidence.

With respect to 'increased self-esteem', the actors talked about increased selfesteem after being involved in the project. They felt more valued according to their own standards. They related this to their experiences of the professionals' respecting and appreciating them. For some of the actors, this was the first time in their lives they had experienced this respect and appreciation. As one of them described, 'They gave us so much and they told us how much they appreciated working with us. We are not used to hearing that'.

Of special importance was the leader's ability to show respect and to see the individual. She understood their struggles and problems and noticed their potential. She inspired them to trust themselves. The actors also underscored the staff's professionalism and that it was rewarding working with them. They felt honoured by this and that they were valuable. As one put it, 'It is like being served strawberries; imagine that I could be seen as worthy of participating in this project!'

Feeling more appreciated also involved becoming more visible, both for themselves and for others. When they had to reveal themselves through singing, dancing, art projects, and standing on stage, they were able to present an image of themselves that they were proud of.

\section{Increased coping ability}

The theme of 'increased coping ability' involved 'energy and vitality', 'personal growth', and 'courage'. Several of the actors emphasized that being part of the project gave them the energy and vigour to participate in both school and theatrical activities. Many had earlier struggled with a lack of energy to start the day. Now they had something to look forward to and something to get up for every morning. However, a few became exhausted by all the new experiences and demands.

The leader supported most of the actors by helping them to organize several unfinished tasks in their personal lives. Most of them had found it difficult to communicate their needs to the public authorities. The leader accompanied them to various offices. They got help with managing their financial and medical problems, receiving adequate dental care, and beginning therapy with a psychologist. Several expressed that they had forgotten the feeling of 
accomplishing such tasks and that this feeling gave them energy. Two actors put it like this:

I've done more in five weeks than in the last two years. I walk around with a very good conscience; all my concerns have somehow disappeared.

It's no big deal to face challenges anymore. I have discovered that the challenges are there all the time and that I can face them as they appear.

Regarding the element of 'personal growth', several pointed out that they had gone through personal growth during the project. Some expressed a feeling of beginning to live. They had developed greater sensory and body awareness. One described it this way:

Here I have had the possibility to crawl, to study, to fantasize, to be part of something. I have had the possibility to explore, to sense, to feel, and to breathe. My body has been allowed to tickle, to get goose bumps, and to shudder.

Some expressed the feeling of becoming grown up through participating in the project. They had developed greater understanding of and patience with themselves and others, and some used the term 'self-development'. One said:

I used to sit at home doing nothing, absolutely nothing, just walking around in a circle. Now I do a lot every day; I go through a sort of self-development. I have become more positive and more ready for new things.

Some told about learning to manage the stress they experienced during all the artistic exposure. They pointed out how important it was to work on themselves. 'To work on myself is the biggest job ever,' one reported.

The element of 'courage' was also critical. At the start of the project, they talked about everything they feared. They feared meeting other people, participating in theatrical games (cf. Boal, 2003), being on stage, singing, and memorizing a text. Yet they found themselves gaining the courage needed to meet these challenges. By participating in the theatrical games, each of them was challenged. They dared to plunge into it and to challenge their own limits. As one enthused, 'We have been challenged in several areas, and we have met these challenges. We dared to do it!'

The actors emphasized the importance of safe professional leadership. The staff were present, kept their spirits up, and encouraged and helped them to set limits for themselves. Most of the actors appreciated that they faced challenges and demands. They found that the challenges were not set too high, but adapted to their individual level of coping. They were able to grow within their own coping limits. One exception was the one who found the requirements for participation as being too ambitious.

\section{Responsibility}

The theme of 'responsibility' encompassed the elements of 'being responsible for oneself' and 'being responsible for others'. The actors elaborated the experience of 'being responsible for oneself' in several areas. One young woman described how important it was that the project required something of her: 'I've learnt that nothing comes by itself: one must give in order to get 
something back'. 'Being responsible for oneself' also had to do with being able to carry out the daily tasks of the project and it became important to create daily routines. Many experienced that life had become more structured and orderly after joining the project. 'It has been necessary to be predictable and to learn to take responsibility for myself'. They emphasized the importance of having a normal circadian rhythm and a firm structure of the day:

I have become more A4. I get up in the morning and go to The Mill (name of the locality), attend the programme, eat lunch, and continue the programme. I say 'goodbye' at three o'clock and come home and have dinner - every day. It has not been like that before, not at all.

With respect to 'being responsible for others', the actors regarded the mandatory attendance in the programme as positive, and being called for and picked up if they did not turn up in the morning. However, after some time, they expressed a feeling of responsibility and a commitment to fulfil the programme, and they came by their own motivation. It became, for example, important to defy illnesses like the flu because they wanted to show up every day and participate in the development of the performance. 'Now we have learned that there are responsibilities and limits to take into account and not just think about ourselves'.

\section{Connectedness to others and society}

'Connectedness to others and society' covered awareness of 'experience of community and reciprocity', 'safety and trust towards other people', and 'social participation'. 'Experience of community and reciprocity' was central to the actors' involvement. In the beginning of the project, many of the actors described a feeling of being socially excluded and not fitting into society. They did not believe they were able to 'fix an ordinary life'. A central line in the theatrical piece Hanging from a thin line was 'l'm longing for a normal life'.

Through the theatrical activities, they became familiar with each other and encountered different sides of each person. They expressed a feeling of being acknowledged by each other. The project was successful in establishing strong bonds of trust and reciprocity between them. 'We are a close-knit and resourceful bunch.' They changed from feeling alienated and alone to belonging to a group. 'The group is like a family where I can be myself.' They emphasized that they learned to listen to each other, to be tolerant, and to accept different opinions. They learned to be more respectful of what the others were going through. They became empowered by the relational activities and seemed to be more visible. Nevertheless, a few actors were more restrained, periodically withdrawing from the community, and stayed alone more.

Actors and staff did a lot together: daily meals, visits to cultural events, theatrical games and exercises, and the development of the performance. By doing things together, they established a sense of community and togetherness between them. This togetherness also seemed to have significance for their feeling of connectedness. The actors were proud of what they had achieved together through the development and presentation of the theatrical performance. They felt that they had reached the audience. A large part of the audience were deeply touched by the performance. Some cried during and after the performance.

The actors also indicated that they cared about each other. They emphasized the experience of 'being in the same boat': they understood each other; they 
were peers. They commented on and noticed the others' development. As one said, 'When you see the eyes of the others there is a reason to smile'. They were moved by the development of the others.

The element of 'safety and trust towards other people' was also salient. There was some evidence that the project had an impact on the actors' relationships outside of the project. Most of them talked about a new feeling of trust towards others: 'I am surprised that I feel so safe when I am with other people no matter who it is'. They also told about getting better contact with people around them during the project's duration. They had re-established contact with family and friends and acquired a healthier network. One of the young men reported that he had something to talk about: he could discuss his experiences from theatrical work, culture arrangements, and so forth with his family. Attending cultural events - visiting the library, cafés, theatre, and concerts - contributed to the actors' participation in the public sphere. It gave them training in participating as citizens in the community.

'Social participation' was another defining experience. The feeling of being connected to others seemed to give the actors the courage and the ability to participate more in society. The actors found that they had developed a greater sense of social participation and of fitting into society. The following dialogue between three actors reflected this view:

Participation in the project means for me to be involved in the actual world and not trapped in my own.

Yes, for me too. The image I have of myself has changed; I do not look at myself as an outsider anymore; now we are insiders. We are ordinary youths.

Agreed. Now we learn to respond to ordinary demands of society, what could be called common norms.

Three of the women rented a house and moved in together. They gave each other important support with regard to emotional and social issues, such as making new friends, addressing hobbies, making school plans, and attending therapy related to substance abuse and mental-health problems. Two actors found each other in a romantic relationship. One of the men got a part-time job in a music store: 'Now they want me, it's cool! Earlier I would not have been able to accept this offer. I wouldn't have known how to apply for it'. Nearly all of the actors applied for courses in high school for the next school year, planning to take exams in the subject Norwegian. One applied for an art education in another Nordic country.

\section{Discussion}

The aim of this study has been to describe and interpret the experiences of young adults not attending school or going to work who participated in inclusive theatre as a means to empowerment, social belonging, and participation. The main finding was 'an expanding positive sense of self' that consists of four categories: increased self-confidence, increased coping ability, responsibility, and connectedness to others and society. We have organized the discussion into two main themes: 1 ) inclusive theatre as a contribution to empowerment and 2) inclusive theatre as a contribution to social belonging and participation. 


\section{Inclusive theatre as contribution to empowerment}

We may understand the main finding of an expanded positive sense of self both at the individual and the group levels. Empowerment in general is both a goal and a means of attaining that goal (Askheim, 2003). Such goals might be positive outcomes of care and social support and may include increased emotional well-being, independence, a motivation to participate, and more effective coping strategies (Ryan et al., 2012).

We shall first look at the findings at the individual level of empowerment, namely, self-empowerment. Individual empowerment has to do with activities and processes relating to the aim of increasing the person's control over his or her life, and equipping the person with more self-confidence, a better perception of oneself, and increased knowledge and skills (Askheim, 2003, p. 230). The findings in our study fit well with this understanding of individual empowerment. Our findings suggest that the actors' feelings of powerlessness dissipated. They became more acting subjects instead of passive recipients of help. They were met as partners (actors) who were responsible for their own lives. It was important that they had the possibility to participate in all decisions concerning the theatrical work and performance. It was also important that they became able to assert their needs in relation to public authorities with help from the staff. In this way the actors learnt to break patterns of beliefs like 'it is no use of trying' and to avoid necessary but unpleasant duties.

For several of the actors it was a new experience that adult persons cared about them for an extended period. The combination of care and demands and clear adult role models influenced the actors in a positive way. It was important that the project not only focused on theatrical activities but also provided practical and social support. In this way the actors got help to meet basic needs by getting access to health and social services. This access connected them to appropriate networks and resources and helped them to master their everyday life (Munford \& Sanders, 2014). Actually being engaged in an ongoing, goaloriented project like this also includes several trivial aspects, like establishing daily routines in one's own life, learning to cook, and so on. It helped them to experience more about living an ordinary life with routines and structure, which allowed for an association with adulthood and strengthen self-confidence (Andvig, Svanoe \& Borg, 2016). The interplay in this project between 'mundane' activities and the relations between the participants themselves and between the participants and the leaders are central to the project's success.

Our findings are also in line with Faigin and Stein (2010), who underscore that theatrical settings focusing on openness and inclusion stimulate the sense of self. These authors relate to research on recovery processes that highlight how a sense of self can be affected when persons with mental-health problems are given possibilities to activate and acknowledge personal strengths. Our findings demonstrate that the actors established a new self-image as competent young persons able to cope with a range of situations in everyday life and to learn practical skills and coping abilities. Boal (1995) emphasizes that theatre is a space where people can rehearse possibilities for changing the image they carry of themselves and the world they live in. Our findings suggest that the theatrical activities gave the actors the opportunity to test out identities and roles and to experiment with different selves. This finding is in line with Munford and Sanders (2014). According to Ryan et al. (2012) empowerment on the individual level involves a process of redefining and negotiation self-identity both with one self and to society as a whole. 
Our findings concerning 'increased coping ability and responsibility' in daily life are also in line with Horghagen and Josephsson (2010), who report that engagement in theatre facilitates personal growth by re-establishing daily routines and promoting feelings of control, self-esteem, and self-actualization. The findings also suggest that the actors and the professionals built relationships characterized by collaboration, openness, respect, and trust. These are all factors that are important conditions for developing empowerment (Askheim, 2003). These findings are also in accordance with findings reported by Bungay and Vella-Burrows (2013), Kemp (2006), and Mohler (2012). Kemp (2006) reports that participating in theatrical activities promotes young people's self-esteem and a positive sense of agency and thus creates opportunities for self-expression, reflection, and self-understanding. Moreover, theatrical activities promotes the development of relationships between participants characterized by trust and reciprocity.

The findings concerning 'increased coping ability' also illuminate the importance of learning to be aware of, express and handle one's own emotions. The dramatic exercises and theatrical activities gave them the possibility to learn from real emotional episodes. According to Larsson and Brown (2007) the theatrical setting makes it possible for individuals to learn from each other how to manage emotions. To write and reflect on their experiences every day seemed to develop their self-reflectiveness, which is important in developing individual empowerment (Boal, 2003, 2006; Freire, 1970). The reading of texts of, for example, the author Knut Hamsun and daily writing exercises also stimulated school-related skills and motivated them to go back to school.

We shall now look at our findings in relation to empowerment at the the group level. Drury et al. (2015) relate the concept of empowerment at the group level to subordinated groups struggling to change their situation and in doing so becoming more conscious of the possibility of making positive changes. Drury et al. claim that subordinated groups may come to see themselves as agents of their own transformation through their actions.

As a group and as an ensemble the actors changed their collective self-image and became active parts of society by making art that aimed to influence their surroundings. This understanding is in line with Freire's ideas of empowerment such as critical consciousness-raising, liberation, and actions resulting from heightened awareness (Freire, 1970). Our findings illustrate the importance of developing artistic expressions based on the actors' own life experiences. According to Gjærum et al. (2010) the performance and the other exhibitions can be seen as a movement where the actors change their collective understanding as isolated from society to understanding themselves as actors and producers of art acclaimed by a broad audience. The authors emphasize that the daily processes and activities at the theatre keep and nurture this new role. According to Horghagen and Josephsson (2010) incorporating participants' own stories into the performance facilitates the growth of respect and appreciation for themselves and each other, and may also be a foundation for their daring to trust others.

By focusing the theatrical work on psychosocial issues regarding their own life situations, the actors also shared common experiences. Their work throughout the year addressed challenges concerning such issues as stigma, isolation, feelings of social exclusion and oppression, and how to fight back as a group. By sharing stories they learned to see their own experiences as a source of knowledge - and to use them as material for the artistic and theatrical work. Sharing stories also seemed to develop a mutual understanding of their life situations, and gave them the possibility to recognize their agency as a group 
who is able to transform their experiences and to share them with an audience outside the project. Boal (1995, p. 16) emphasizes the importance of working on issues that are real and urgent in the lives of the actors, something in which 'they have an investment, situations in which they venture their lives and their feelings, their moral and their political choices'. According to Faigin and Stein (2010) the commonalities in the lived experiences may serve as a mutually supportive function, creating an environment where processes of personal change can occur and group empowerment is enhanced. Butler et al. (2013) hold that by, for example, sharing the performance, art, and concerts, the group affirms what they have learned and created. Such documentation makes change more sustainable and confirms the participants' newly developed views of themselves, communicates with others, and makes them part of society (Butler et al., 2013). It was also essential that the audience included important adults and their peers, professionals from the Norwegian Labour and Welfare Service, teachers, persons who may have been affected by how they meet young people at school and in care systems (Salmon \& Rikaby, 2014).

\section{Inclusive theatre as contributing to social belonging and participation}

The findings concerning responsibility for others, being part in a joint project, the experience of community and reciprocity, and trusting others might be understood as social belonging. A sense of belonging can be defined as 'a subjective feeling of value and respect derived from a reciprocal relationship to an external referent that is built on a foundation of shared experiences, beliefs or personal characteristics' (Mahar et al., 2013, p. 1031). A sense of belonging is related to a feeling of connectedness and fitting in somewhere, to a referent group, such as peers (Mahar et al., 2013). According to these authors achieving a sense of belonging requires that the person perceives that he or she is valued, respected, and in other ways subjectively engaged. The findings illustrate that through the year of theatrical work the actors became an active part of the world around them and developed a feeling of having something in common. They developed a strong reciprocal relationship with other members of the group and with the staff. The members of the group learnt to communicate and cooperate with each other and to develop a feeling of community. They established themselves as an ensemble, working, playing and accomplishing something worthwhile together. Gjærum and Rasmussen (2010) emphasize the importance of creating a particular 'us' spirit, which is expressed through the fellowship of the group. The sense of belonging to such a fellowship prevailing at the theatre is, according to these authors, crucial to the actors' selfunderstanding and self-image. Mohler (2012) confirms the importance of having fun and play and claims that the opportunity to play is transformative. Mohler elaborates that playing through the use of theatre games gives a break from the more serious aspects of the lives of the actors, and may assist the process of establishing a new kind of community with their peers based on the common experience of having fun. The experience of reciprocity through shared feelings, experiences, and understanding supported by the group is important in the creation of a sense of belonging (Mahar et al., 2013). Mahar et al. also emphasize the importance of having the power to self-determination and choosing whom you want to belong to.

The findings show that there is a connection between feelings of community, social belonging, and social participation. Faigin and Stein (2010) emphasize that theatrical work offers a bridge between personal development and community integration for people with mental-health problems. They highlight that the inclusive nature of the theatrical setting connects the person to the local community. Munford and Sanders (2014) also focus this connection by pointing 
out that the feeling of being included in society and being able to exercise agency is connected to a sense of belonging and an ability to exercise citizenship. This is stimulated by being part of family and social networks, and having meaningful activities.

However, the sense of reciprocity and belonging between the participants and between the participants and the leaders was to some extent put under pressure in the run-up to the performance. Because of this pressure one participant dropped out because of stress. In this phase the leaders could have been more sensitive and taken more individual consideration with fewer demands on those who felt highly stressed.

Inclusive theatre has several aspects in common with other supported activities such as Individual Placement and Support (IPS) and Green Care for young people, such as the resource orientation, having the possibility to work with things you are interested in, getting support and supervision at the actual work place, gaining experience with coping, and being part of a community. Young people's experiences from participating in IPS and Green Care are also in accordance with the actors who participated in this project. They too experienced increased coping ability, self-confidence, and a feeling of connectedness to others. Yet one aspect seems to be different: inclusive theatre, in the form inspired by Freire and Boal, gives the participants the possibility to make their voices heard in the public arena, to work with resolving social frustrations and conflicts, and through consciousness-raising to be able to fight through difficult situations.

\section{Implications for practice}

Young people at risk have to be taken seriously by schools, NAV, the workplace, and the health and social services. They need to be seen, understood, and followed up systematically. It is important that the follow-up is holistic and kept within the framework of everyday life. The support must stimulate the young people to take part in everyday life activities. The support must be adapted to the individual according to his or her life situation and potential.

Theatre and the use of several forms of art and exhibitions appear to work well as methods for social work with young people at risk. Similar social-work projects could focus on young people at risk with other kinds of interests. It could be possible to develop other kinds of teamwork arrangements throughout a school year for young people. They could participate in groups together with adult teachers and coaches in activities, such as playing football, sailing, nature expeditions, and so on. A challenge for this endeavour would be to maintain the working form inspired by the liberating, inclusive ideology of Augusto Boal and Paolo Freire.

Projects over one year are not enough for this group of young people. We envisage that the project will go forward into a phase with increased demands and progressively connected to ordinary school and working life. At the same time, creative methods should have their place, but to a lesser extent. The youths are dependent on safe and predictive frames and long-term planning. 


\section{Implications for future research}

It would be interesting to see similar studies done on other related initiatives, such as alternative work training, development of alternative learning arenas outside of schools, and networks of support for youth in the process of being excluded.

\section{Conclusion}

Through increased self-esteem, the actors have explored opportunities to form their own development and to find a way to pursue further avenues as part of society. They have dared to meet the challenges which have provided them with good experiences and more meaning in their lives. They have gone through a social process of empowerment, recognizing, promoting, and strengthening their ability to satisfy their own needs, and involving a mobilization of the resources needed in order to feel in control of their own life. They have begun to believe in a future that includes education, work, and friends.

\section{Acknowledgments}

We wish to thank Professor Anne Lyberg for participating in the data collection and in discussing the preliminary data analysis.

\section{References}

Andvig, E. (2014). Förundran i hermeneutisk forskning - ett exempel från fokusgruppsamtal [Wonder in hermeneutic research: an example from focusgroup discussions]. In E. Lassenius \& E. Severinsson (eds.) Hermeneutik $i$ vårdpraxis. Det nära, det flyktiga, det dolda. [Hermeneutic in the caring practice: The close, the fleeting, the hidden]. Malmø: Gleerups Utbildning AB.

Andvig, E., Svanoe, K. \& Borg, M. (2016). Gaining a Foothold: How Housing and Belonging Support Youth-at-risk in Getting a Grip on Adulthood. Open Journal of Social Sciences, 4, 26-37. http://dx.doi.org/10.4236/jss.2016.41004

Askheim, O.P. (2003). Empowerment as guidance for professional social work: an act of balancing on a slack rope. European Journal of Social Work, 6(3), 229-240. DOI: 10.1080/1369145032000164546

Bhukanwala, F. (2014). Theater of the oppressed in an after-school program: Middle school students' perspectives on bullying and prevention. Middle School Journal, 46(1), 3-12.

Boal, A. (1995). The Rainbow of desire: The Boal method of theatre and therapy. London: Routledge.

Boal, A. (1998). Legislative Theatre. New York: Routledge.

Boal, A. (2003). Games for actors and non-actors. New York: Routledge.

Boal, A. (2006). The aesthetics of the oppressed. New York: Routledge. 
Bond, G.R., Drake, R.E. \& Campbell, K. (2012). The effectiveness of the Individual Placement and Support model of supported employment for young adults: results from four randomized controlled trials. Early Intervention in Psychiatry, 6(supplS1), 30 .

Bungay, H. \& Vella-Burrows, T. (2013). The effects of participating in creative activities on the health and well-being of children and young people: a rapid review of the literature. Perspectives in Public Health, 133(44), 44-52. DOI: $10.1177 / 1757913912466946$

Butler, E., Bakker, T.E. \& Viljoen, G. (2013). Poetic and therapeutic encounters in an adolescent drama group. South African Journal of Psychology 43(1), 94-104. DOI: $10.1177 / 0081246312474413$

Costello, E.J., Egger, H. \& Angold, A. (2005). 10-year research update review: the epidemiology of child and adolescent psychiatric disorders: Methods and public health burden. Journal of American Academic Child Adolescent Psychiatry, 44(10), 972-986.

Daykin, N., Orme, J., Evans, D., Salmon, D., McEachran, M. \& Brain, S. (2008). The Impact of Participation in Performing Arts on Adolescent Health and Behaviour. A Systematic Review of the Literature. Journal of Health Psychology, 13(2), 251 264.

Drake, R.F. \& Becker, D.R. (2006). The individual placement and support model of supported employment. Psychiatric Services, 47(5), 473-475.

Drury, J., Evripidou, A. \& van Zomeren, M. (2015). Empowerment: The intersection of identity and power in collective action. In D. Sindic, M. Barreto \& R. Costa-Lopes (Eds.), Power and identity (pp. 94-117). London: Psychology Press.

Ellison, M.L., Klodnick, V.V., Bond, G.R., Krzos, I.M., Kaiser, S.M. \& Fagan, M.A. (2014). Adapting supported employment for emerging adults with serious mental health conditions. Journal of Behavioral Health Services and Research. 42(2), 206-222.

Faigin, D.A. \& Stein, C. H. (2010). The Power of Theater to Promote Individual Recovery and Social Change. Psychiatric Services, 61(3), 306-308.

Follesø, R. (ed.) (2011). Gi Viljen Mulighet! Sluttrapport Ungdom i Svevet 2007-2010 [Give the Will a Possibility. Final Report Youth in Flight] UIN-rapport vol.12. Bodø: Universitetet i Nordland.

Freire, P. (1970). Pedagogy of the oppressed. New York: Continuum International Publishing Group Inc.

Gjærum, R.G., Ineland, J. \& Sauer, L. (2010). The Story about Theater Organizations, the Public's Approval, and the Actors' Identity Formation in Nordic Disability Theater. Journal of Social Work in Disability \& Rehabilitation 9(4), 254-273 DOI:10.1080/1536710X.2010.523648

Gjærum, R.G. \& Rasmussen, B. (2010). The Achievements of Disability Art: A Study of Inclusive Theatre, Inclusive Research, and Extraordinary Actors, Youth Theatre Journal, 24(2), 99-110, DOI: 10.1080/08929092.2010.518909

Graneheim, U.H., \& Lundman, B. (2004). Qualitative content analysis in nursing research: concepts, procedures and measures to achieve trustworthiness. Nurse Education Today, 24(2), 105-112.

Granerud, A. \& Eriksson, B.G. (2014). Mental Health Problems, and the Impact of Green Care Services: A qualitative, Participant-Focused Approach. Occupational Therapy in Mental Health, 30(4), 317-336. 
Gürgens, R. (2004). En usedvanlig estetikk: om betydningen av egenproduserte teatererfaringer for det usedvanlige mennesket. [An extraordinary aesthetic: The meaning of self-produced theatrical experiences for the extraordinary person]. Trondheim: NTNU- trykk.

Halvorsen, B., Hansen, O.J. \& Tägtström, (2012). Unge på kanten. Om inkludering av utsatte ungdommer. [Youth at the edge. On including youth at risk]. Nordisk ministerråd 2012:005.

Hawkins, S.T. \& Georgokopolus, A. (2010). Dramatic Problem Solving: Community Conflict Transformation through Interactive Theatre in Costa Rica. International Journal of Arts and Sciences, 3(8), 545-560.

Horghagen, S. \& Josephsson, S. (2010). Theatre as Liberation, Collaboration and Relationship for Asylum Seekers. Journal of Occupational Science, 17(3), 168176.

Hummelvoll J.K. (2008). The multistage focus group interview: A relevant and fruitful method in action research based on a co-operative inquiry perspective. Norsk Tidsskrift for Sykepleieforskning, 10(1), 3-14.

Hummelvoll, J.K. \& Severinsson, E. (2005). Researchers' experience of co-operative inquiry in acute mental health care. Journal of Advanced Nursing, 52(2), 80-188.

Hyggen, C. (2015). Unge utenfor utdanning og arbeid i Norden. Utfordringer, innsatser og anbefalinger. [Young people outside education and work in the North. Challenges, initiatives and suggestions]. Nordisk Ministerråd, Tema Nord, 2015:536 http://dx.doi.org/10.6027/TN2015-536

Kane, K.M. (2013). Best Practices in the Performing Arts Transformation and Flourishing in a Progressive Summer Dance Theater Program for Adolescents. Journal of Dance Education, 13(3), 71-77. DOI: 10.1080/15290824.2013.810341

Kemp, M. (2006). Promoting the health and wellbeing of young black men using community-based drama. Health Education, 106(3), 186-200.

Kogstad, R.E., Agdal, R. \& Hopfenbeck, M.S. (2014). Narratives of Natural Recovery: Youth Experience of Social Inclusion through Green Care. International Journal of Environmental Research and Public Health, 11(6), 6052-6068. DOI: 10.3390/ijerph110606052

Langeland, S., Herud, E. \& Ohrem, S. (2014). Fattigdom og levekår i Norge - status 2013. [Poverty and living conditions - status 2013]. NAV-rapport 2014, nr.1. Arbeids- og velferdsdirektoratet.

Larson, R.W. \& Brown, J.R. (2007). Emotional development in adolescence: what can be learned from a high school theater program? Child Development, 78(4), 10831099.

Lee, S., Tsang, A., Breslau, J., Aguilar-Gaxiola, S., Angermeyer, M., Borges, G., et al. (2009). Mental disorders and termination of education in high-income and lowand middle-income countries: Epidemiological study. British Journal of Psychiatry, 194(5), 411-417. DOI: 10.1192/bjp.bp.108.054841

Mahar, A.L., Cobigo, V. \& Stuart, H. (2013). Conceptualizing belonging. Disability \& Rehabilitation, 35(12), 1026-1032.

Mohler, C.E. (2012). How to turn 'a bunch of gang-bangin' criminals into big kids having fun': Empowering Incarcerated and At-Risk Youth through Ensemble Theatre. Theatre Topics, 22(1), 89-102. DOI: 10.1353/tt.2012.0002 
Munford, R. \& Sanders, J. (2014). Negotiating and Constructing Identity: Social Work with Young People Who Experience Adversity. British Journal of Social Work, 45(5). DOI: 10.1093/bjsw/bcu059

NOU (2009, No.22) (Norwegian Official Report), Whatever you do, do it well - better coordination of services for children and adolescents, Ministry of Children, Equality and Social Inclusion.

NOVA (Norwegian Social Research), (2014). Ungdata -Nasjonale resultat 2013 [Youth Data - National results 2013] Report No. 10/14. Oslo: Norwegian Social Research Institute.

Patel, V., Flisher, A.J., Hetrick, S., McGorry, P. (2007). Mental health of young people: a global public-health challenge. Lancet, 369(9569), 1302-1313.

Ramsdal, G., Gjærum, R.G., \& Wynn, R. (2013). Dropout and early unemployment. International Journal of Educational Research, 62(6), 75-86.

Rumberger, R.W. \& Lim, S.A. (2008) Why Students Drop Out of School. A Review of 25 years of research. California Dropout Research Project. Santa Barbara: University of California.

Ryan, P., Baumann, A.E. \& Griffiths, C. (2012). Empowerment: Key Concepts and Evidence Base. In P. Ryan, S. Ramon \& T. Greacen, (Eds.), Empowerment, Lifelong Learning and Recovery in Mental Health: Towards a new paradigm (pp. 135-203). New York: Palgrave Macmillan.

Salmon, D. \& Rikaby, C. (2014). City of One: A Qualitative Study Examining the Participation of Young People in Care in a Theatre and Music Initiative. Children \& Society, 28(1), 30-41. DOI:10.1111/j.1099-0860.2012.00444.x

Settersten, R.A. \& Ray, B. (2010). What's going on with young people today? The long and twisting path to adulthood. The future of children, 20(1), 19-41.

Statistics Norway (2013). Gjennomstrømming I videregående opplæring 2007 - 2012. [Passing in Upper Secondary Education 2007-2012]. www.ssb.no/vgogjen.

Steigen, A.M, Kogstad R. \& Hummelvoll, J.K. (2015). Green Care services in the Nordic countries: an integrative literature review. European Journal of Social Work, 19(5), DOI: 10.1080/13691457.2015.1082983

The Norwegian Ministry of Health (2014-15). Melding til Stortinget nr. 19 (2014-15). Folkehelsemeldingen. Mestring og muligheter. [White paper on health promotion. Coping and possibilities]

Thompson, S.J., Ryan, T.N., Montgomery, K.L., Lippman, A., Bender, K. \& Ferguson, K. (2013). Perceptions of resiliency and coping: homeless young adult speak out. Youth Society, 48(1), 58-76. DOI: 10.1177/0044118X13477427.

WHO, (1998). The World Health Report. Life in the $21^{\text {st }}$ century: a vision for all. Geneva.

Woodall, J.R., Warwick-Booth, L. \& Cross, R. (2012). Has empowerment lost its power? Health Education Research Advance Access, 27(4), 742-745. DOI:10.1093/her/cys064

Wooster, R. (2009). Creative inclusion in community theatre: a journey with Odyssey Theatre. Journal of Applied Theatre and Performance, 14(1), 79-90.

World Medical Association (2008). The Declaration of Helsinki. Ethical principles for medical research involving human subjects. Retrieved from Http:// www.wha.net/en/30publications/10policies/b3/. 